\title{
Angka Kejadian dan Faktor yang Memengaruhi Potensi Interaksi Obat dengan Obat pada Pasien Leukemia Akut Anak yang Menjalani Rawat Inap
}

Sri Wulandah Fitriani, ${ }^{*}$ Rina Mutiara, ${ }^{* *}$ Amarila Malik, ${ }^{*}$ Murti Andriastuti***

${ }^{*}$ Fakultas Farmasi Universitas Indonesia, ${ }^{* *}$ Instalasi Farmasi RSUPN Dr. Cipto Mangunkusumo, ${ }^{* * *}$ Fakultas Kedokteran Universitas Indonesia/RSUPN Dr. Cipto Mangunkusumo, Jakarta

Latar belakang. Risiko terjadinya potensi interaksi obat dengan obat (PIOO) pada pasien leukemia akut akibat pemberian terapi multidrug cukup tinggi.

Tujuan. Mengetahui angka kejadian dan faktor yang memengaruhi PIOO pada subjek penelitian.

Metode. Penelitian dilakukan dengan metode potong lintang. Pengambilan data dilakukan secara retrospektif terhadap pasien leukemia akut pada anak yang menjalani rawat inap di RSCM pada Januari - Desember 2014. Identifikasi PIOO dilakukan menggunakan perangkat lunak Micromedex Drug Reax ${ }^{\odot}$.

Hasil. Didapat 96 subjek yang memenuhi kriteria penelitian. Subjek berpotensi mengalami PIOO 41,6\% dengan tingkat keparahan kontraindikasi $(4,70 \%)$, berat $(60,70 \%)$, dan sedang (34,60\%). Jenis PIOO paling sering adalah deksametason dan flukonazol yang berpotensi meningkatkan paparan glukokortikoid. Terdapat perbedaan bermakna pada faktor usia $(p=0,037)$, lama hari rawat $(\mathrm{p}=0,000)$, dan rerata jumlah obat $(\mathrm{p}=0,000)$, sedangkan komorbiditas tidak menunjukkan perbedaan $(\mathrm{p}=0,082)$.

Kesimpulan. Angka kejadian PIOO pasien leukemia akut pada anak yang menjalani rawat inap di RSCM adalah 41,6\%. Faktor usia, lama hari rawat, dan rerata jumlah obat berpengaruh signifikan terhadap kejadian PIOO dengan nilai OR 1,8 terhadap pasien berusia $>7$ tahun, 6,3 terhadap pasien dengan lama hari rawat $>7$ hari, dan 5,3 terhadap pasien dengan rerata pemberian $>4$ obat per hari. Sari Pediatri 2016;18(2):129-36

Kata kunci: kemoterapi, interaksi obat, leukemia akut, micromedex, pediatrik.

\section{Figures Genesis and Factors of Potential Drug-Drug Interactions in Pediatric Inpatient with Acute Leukemia}

Sri Wulandah Fitriani, Rina Mutiara, Amarila Malik, Murti Andriastuti

Background. Risk of potential drug-drug interactions (pDDIs) in patients with acute leukemia due to administration of multidrug therapy is quite high, and studies in pediatric patients have not been done before.

Objectives. To determine the incidence and factors that affect pDDIs.

Methods. A cross-sectional study design with the subjects of pediatric inpatient with acute leukemia in RSCM from January to December 2014. Data obtained through the electronic prescription retrospectively. PDDIs were identified by Micromedex Drug Reax software.

Results. Ninety six pediatric inpatient fulfilled the criteria. PDDIs were identified in $41,6 \%$ samples with the severity of contraindications $(4,70 \%)$, major $(60,70 \%)$, and moderate $(34,60 \%)$. The most frequent pDDIs involved dexamethasone and fluconazole that potentially increased glucocorticoid exposure. There are significant differences in the factor of age ( $\mathrm{p}=0.037)$, length of stay (LOS) ( $\mathrm{p}=0.000)$, and the mean number of medications $(\mathrm{p}=0.000)$, while comorbidity showed no significant difference $(\mathrm{p}=0.082)$.

Conclusions. Incidence rates of pDDIs in pediatric inpatient with acute leukemia in RSCM is $41.6 \%$. Age, LOS, and the mean number of medications have significant differences on the incidence of pDDIs with OR 1.8 for the patients aged $>7$ years, 6.3 for the patients with LOS $>7$ days, and 5.3 of the patients with $>4$ drugs given per day. Sari Pediatri 2016;18(2):129-36

Keywords: chemotherapy, drug interactions, leukemia, micromedex, pediatric

\footnotetext{
Alamat korespondensi: Sri Wulandah Fitriani, Dr. Murti Andriastuti, SpA(K). Fakultas Farmasi, Fakultas Kedokteran Universitas Indonesia. E-mail: sri.wulandah@gmail.com
} 
Sri Wulandah Fitriani dkk: Angka kejadian dan faktor yang memengaruhi potensi interaksi obat dengan obat pasien leukemia akut

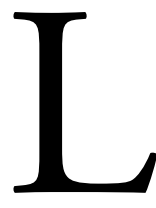

eukemia merupakan kanker yang paling sering menyerang anak dengan puncak insiden antara umur 3 dan 4 tahun. American Cancer Society melaporkan bahwa pada tahun 2009 terjadi \pm 1380 kematian pada anak usia 0-14 tahun akibat kanker dan sepertiganya disebabkan oleh leukemia. ${ }^{1}$ Data RSCM juga menyebutkan bahwa sedikitnya terdapat 50 pasien leukemia anak baru setiap tahunnya dengan persentase leukemia akut lebih besar. ${ }^{2}$

Kemajuan strategi pengobatan leukemia memberikan pengaruh besar terhadap kualitas dan kelangsungan hidup pasien. Angka kesintasan terus meningkat. Lebih dari $85 \%$ pasien leukemia limfositik akut (LLA) dan 60\%-70\% pasien leukemia mieloid akut (LMA) pada anak dapat mencapai remisi penuh. ${ }^{3}$ Angka kesintasan pasien leukemia anak di Indonesia jauh lebih rendah. Berdasarkan studi yang dilakukan Permatasari $\mathrm{dkk}^{4}$ diketahui bahwa angka kesintasan 5 tahun pasien LLA anak risiko biasa (RB) dan risiko tinggi (RT) masing-masing adalah 48\% dan 19\%, sedangkan persentase kejadian relaps pada kedua kelompok tersebut 48,7\% dan 17,8\%. Kepatuhan pasien yang rendah terhadap kemoterapi dinilai sebagai salah satu penyebab dihasilkannya pengobatan yang tidak efektif dan mengarah pada peningkatan angka kekambuhan.

Interaksi obat merupakan salah satu penyebab penting terjadinya reaksi obat yang tidak dikehendaki (ROTD) yang dapat berakibat pada ketidakpatuhan atau kejadian putus obat., ${ }^{5,6}$ Potensi interaksi obat dengan obat (PIOO) didefinisikan sebagai modifikasi efek suatu obat akibat obat lain yang diberikan secara bersamaan sehingga efektifitas atau toksisitas obat tersebut berubah. ${ }^{7-9}$ Akibat PIOO yang lebih membahayakan adalah timbulnya penyakit lain yang dapat memperpanjang lama hari rawat, menambah biaya perawatan, bahkan menyebabkan kematian., $6,10,11$

Pasien leukemia memperoleh beberapa jenis obat dalam waktu yang bersamaan, di antaranya untuk menyembuhkan keganasan, mengatasi toksisitas akibat kemoterapi, dan penyakit penyerta lain seperti nyeri, mual, muntah, dan depresi. Selain itu, pasien leukemia juga mengalami penurunan daya tahan tubuh, baik akibat perburukan gejala klinis maupun sebagai respon kemoterapi sehingga pasien rentan terinfeksi virus, jamur, dan bakteri. Oleh karena itu dibutuhkan adanya tambahan terapi yang dapat meningkatkan kompleksitas pengobatan dan memungkinkan terjadinya interaksi obat dengan obat. ${ }^{8,12}$
Empat persen kematian pasien kanker disebabkan interaksi obat yang berat. ${ }^{13}$ Perubahan farmakokinetik, lama hari rawat, dan kompleksitas pengobatan pasien menjadi salah satu faktor pendukung terjadinya interaksi obat. ${ }^{9,14}$

Berbeda dengan pasien geriatri, informasi kejadian PIOO pada pasien anak sangat terbatas dan belum ada penelitian yang dikhususkan terhadap pasien kanker anak. ${ }^{6,12,15}$ Feinstein $\mathrm{dkk}^{15}$ melaporkan bahwa sedikitnya terdapat satu pasang kombinasi obat yang berpotensi menyebabkan interaksi pada 498.956 (49\%) kasus rawat inap pasien anak di rumah sakit yang tergabung dalam Children's Hospital of Philadelphia. Dampak klinis yang paling banyak terjadi akibat PIOO tersebut adalah depresi per-napasan $(21 \%)$, risiko perdarahan (5\%) dan perpan-jangan interval QT (4\%) yang dapat membahayakan pasien. ${ }^{15}$

Rumah Sakit Dr. Cipto Mangunkusumo merupakan rumah sakit rujukan nasional yang telah merawat pasien leukemia anak selama bertahun-tahun. Akan tetapi, hingga saat ini belum pernah dilakukan penilaian terhadap angka kejadian PIOO pada kasus tersebut. Berdasarkan uraian tersebut, perlu dilakukan penelitian untuk mengetahui angka kejadian PIOO pasien leukemia akut pada anak yang menjalani rawat inap di RSCM dan faktor yang memengaruhinya. Hasil penelitian ini selanjutnya dapat menjadi masukan bagi tenaga kesehatan dalam usaha pengoptimalan pengobatan agar dapat menekan angka relaps pasien leukemia anak.

\section{Metode}

Penelitian dengan metode potong lintang dan dilakukan di RSCM selama bulan Februari-Juni 2016. Pengumpulan data dilakukan terhadap pasien leukemia akut pada anak yang menjalani rawat inap di RSCM periode Januari-Desember 2014. Kriteria inklusi sampel penelitian adalah pasien usia pasien 0 - 18 tahun dan/atau terdaftar sebagai pasien, memiliki diagnosis penyakit leukemia akut (C91 atau C92), baik tunggal maupun bersama dengan penyakit lain, dan memperoleh resep lebih dari 1 jenis obat per hari saat menjalani rawat inap.

Kriteria eksklusi adalah sediaan farmasi yang diberikan bekerja secara lokal dan sediaan farmasi yang diberikan tidak mengandung zat aktif.

Analisis identifikasi PIOO digunakan perangkat lunak Micromedex Drug Reax ${ }^{\oplus}$ dengan penge- 
Sri Wulandah Fitriani dkk: Angka kejadian dan faktor yang memengaruhi potensi interaksi obat dengan obat pasien leukemia akut

lompokkan berdasarkan klasifikasi berikut, ${ }^{16}$

a. Tingkat keparahan

- Kontraindikasi (contraindication): tingkat keparahan interaksi obat tertinggi yang membutuhkan pengawasan secara ketat terhadap dampak klinis yang tidak dikehendaki apabila kedua obat diberikan secara bersamaan.

- Berat (major): interaksi obat berpotensi mengancam nyawa atau menimbulkan gangguan permanen pada pasien sehingga dibutuhkan adanya intervensi medis untuk mencegah atau meminimalisasi dampak negatif yang dihasilkan.

- $\quad$ Sedang (moderate): interaksi obat berpotensi memperburuk kondisi pasien sehingga mungkin dibutuhkan adanya perubahan terapi.

- Ringan (minor): interaksi obat hanya memberikan sedikit pengaruh terhadap respon terapeutik obat, dampak klinis kurang signifikan, dan tidak dibutuhkan adanya perubahan regimen terapi.

b. Tingkat kesahihan bukti dokumentasi

- Sangat baik (excellent): data PIOO didasarkan pada hasil penelitian eksperimental.

- $\quad$ Baik (good): data PIOO didasarkan pada bukti dokumentasi kasus, tetapi belum didukung oleh bukti penelitian eksperimental yang kuat.

- Kurang baik (fair): data PIOO didasarkan pada dugaan interaksi terhadap obat lain yang memiliki kesamaan mekanisme farmakologi dengan dukungan bukti penelitian yang kuat.

c. Onset kejadian PIOO

- Cepat: dampak klinis akibat interaksi obat terlihat dalam waktu kurang dari 24 jam setelah pemberian kombinasi obat.

- Tertunda: dampak klinis akibat interaksi obat baru dapat terlihat setelah lebih dari 24 jam pemberian kombinasi obat.

- Tidak diketahui: waktu terjadinya dampak klinis akibat interaksi obat tidak dapat diprediksi.

d. Mekanisme PIOO

- Farmakokinetik: interaksi obat menyebabkan perubahan absorpsi, distribusi, metabolisme, dan/atau ekskresi obat lain sehingga berpotensi meningkatkan atau mengurangi jumlah obat yang tersedia dalam tubuh.
- Farmakodinamik: interaksi obat disebabkan karena adanya kompetisi pada reseptor yang sama sehingga berpotensi meningkatkan atau menghambat efek farmakologis suatu obat.

- Tidak diketahui: mekanisme interaksi obat belum diketahui secara pasti.

Interaksi obat, apabila terdapat kombinasi obat yang berpotensi mengalami interaksi obat dengan obat dengan tingkat keparahan kontraindikasi, berat, dan/atau sedang dalam satu kali periode rawat inap. $^{6,15}$ Tingkat PIOO dengan keparahan ringan tidak diikutsertakan dalam penelitian karena hanya memberikan sedikit pengaruh terhadap respon terapeutik obat, dampak klinis kurang signifikan, dan tidak dibutuhkan adanya perubahan regimen terapi. ${ }^{8}$

Instrumen atau alat pengumpulan data yang digunakan berupa borang penelitian yang mengacu pada kerangka konsep penelitian. Sumber data berasal dari dokumen resep elektronik pasien. Dilakukan pencatatan usia/tanggal lahir pasien, tanggal mulai dan berakhirnya rawat inap, diagnosis komorbiditas, dan pengobatan yang diberikan selama menjalani rawat inap, kemudian dilakukan analisis interaksi obat menggunakan perangkat lunak dan perangkat lunak Micromedex Drug-Reax .

Analisis data dilakukan secara univariat dan bivariat dengan SPSS for Windows versi 20.0. Analisis bivariat dilakukan menggunakan uji kai kuadrat. Confidence interval yang digunakan adalah $95 \%$ dengan power test $80 \%$.

\section{Hasil}

Selama penelitian berlangsung, didapatkan 107 pasien leukemia akut pada anak yang menjalani rawat inap di RSCM selama periode Januari-Desember 2014. Sebelas subjek dieksklusi karena menerima kurang dari satu jenis obat per hari rawat. Total kunjungan rawat inap pasien leukemia akut pada anak selama periode Januari sampai dengan Desember 2014 diperoleh 214 kunjungan.

Berdasarkan data pengobatan subyek penelitian, tercatat 78 pasien $(81,3 \%)$ menjalani $1-3$ kali rawat inap, 17 pasien (17,7\%) menjalani 4-6 kali rawat inap, dan 1 pasien menjalani 9 kali rawat inap selama tahun 2014. Pasien dengan jumlah kunjungan rawat inap terbanyak diketahui memiliki riwayat komorbiditas 
Sri Wulandah Fitriani dkk: Angka kejadian dan faktor yang memengaruhi potensi interaksi obat dengan obat pasien leukemia akut

Tabel 1. Karakteristik subjek

\begin{tabular}{lcc}
\hline Karakteristik & $\begin{array}{c}\text { Frekuensi } \\
(\mathrm{n}=96)\end{array}$ & $\begin{array}{c}\text { Persentase } \\
(\%)\end{array}$ \\
\hline $\begin{array}{l}\text { Jenis kelamin } \\
\quad \text { Perempuan }\end{array}$ & 38 & 39,6 \\
$\quad$ Laki-laki & 58 & 60,4 \\
Usia (tahun) & & \\
$\quad \leq 7$ & 56 & 58,3 \\
$\quad>7$ & 40 & 41,7 \\
$\quad$ Median (rentang) & $6(1-20)$ & - \\
Jenis diagnosis & & \\
Leukemia limfositik akut & 89 & 92,7 \\
Leukemia mieloid akut & 7 & 7,3 \\
Jumlah kunjungan rawat & & \\
inap (kali) & & \\
$\quad$ 1-3 & 78 & 81,3 \\
4-6 & 17 & 17,7 \\
$>6$ & 1 & 1,0 \\
$\quad$ Median (rentang) & $2(1-9)$ & - \\
\hline
\end{tabular}

berat yaitu perdarahan intrakranial dan febril neutropenia sehingga dimungkinkan perlu adanya pengawasan tenaga kesehatan secara intensif dengan rata-rata lama hari rawat sebanyak 8 hari. Karakteristik
Tabel 2. Angka kejadian PIOO

\begin{tabular}{lcc}
\hline & Frekuensi & Persentase (\%) \\
\hline Kejadian PIOO & \multicolumn{2}{c}{41,6} \\
Ya & 125 & 58,4 \\
Tidak & 214 & 100 \\
Jumlah & \multicolumn{2}{c}{} \\
\multicolumn{3}{c}{ Jumlah kombinasi PIOO per periode rawat inap } \\
1-2 & 47 & 52,81 \\
$3-5$ & 23 & 25,84 \\
$\geq 6$ & 19 & 21,35 \\
Median & $2(1-18)$ & - \\
\hline
\end{tabular}

subjek tertera pada Tabel 1 .

Berdasarkan data kunjungan rawat inap pasien leukemia akut pada anak di RSCM periode Januari sampai dengan Desember 2014, diperoleh angka kejadian PIOO seperti tertera pada Tabel 2.

Berdasarkan pengelompokan Micromedex Drug Reax ${ }^{\oplus}$, diperoleh karakteristik kombinasi PIOO yang teridentifikasi seperti tertera pada Tabel 3. Untuk mengetahui hubungan faktor yang diduga berpengaruh terhadap kejadian PIOO pada subjek dilakukan analisis bivariat. Adanya hubungan antara faktor determinan dengan kejadian PIOO ditunjukkan dengan nilai

Tabel 3. Karakteristik kombinasi PIOO yang teridentifikasi

\begin{tabular}{|c|c|c|c|}
\hline Parameter pengelompokan & Kriteria & $\begin{array}{l}\text { Frekuensi pada } 107 \text { pasang } \\
\text { kombinasi PIOO } \\
\mathrm{n}(\%)\end{array}$ & $\begin{array}{l}\text { Frekuensi pada } \\
1000 \text { kasus PIOO } \\
\text { n (\%) }\end{array}$ \\
\hline \multicolumn{4}{|l|}{ Tingkat keparahan } \\
\hline & Kontraindikasi & $5(4,70)$ & $76(7,60)$ \\
\hline & Berat & $65(60,70)$ & $456(45,60)$ \\
\hline & Sedang & $37(34,60)$ & $468(46,80)$ \\
\hline \multicolumn{4}{|c|}{ Tingkat kesahihan bukti dokumen } \\
\hline & Sangat baik & $12(11,20)$ & $217(21,70)$ \\
\hline & Baik & $37(34,60)$ & $199(19,90)$ \\
\hline & Kurang baik & $58(54,20)$ & $584(58,40)$ \\
\hline \multicolumn{4}{|l|}{ Onset/ lama kejadian } \\
\hline & Cepat & $14(13,1)$ & $177(17,70)$ \\
\hline & Tertunda & $31(29,0)$ & $155(15,50)$ \\
\hline & Tidak diketahui & $62(57,90)$ & $668(66,80)$ \\
\hline \multicolumn{4}{|l|}{ Mekanisme PIOO } \\
\hline & Farmakokinetik & $46(42,99)$ & $478(47,80)$ \\
\hline & Farmakodinamik & $39(36,45)$ & $325(32,50)$ \\
\hline & Tidak diketahui & $22(20,56)$ & $197(19,70)$ \\
\hline
\end{tabular}


Sri Wulandah Fitriani dkk: Angka kejadian dan faktor yang memengaruhi potensi interaksi obat dengan obat pasien leukemia akut

Tabel 4. Hasil uji bivariat pengaruh variabel bebas terhadap kejadian PIOO

\begin{tabular}{lccccc}
\hline \multirow{2}{*}{ Parameter } & & \multicolumn{2}{c}{ PIOO } & OR IK95\% & Sig. \\
\cline { 3 - 4 } & & $\begin{array}{c}\text { Tidak ada } \\
\mathrm{n}(\%)\end{array}$ & $\begin{array}{c}\text { Ada } \\
\mathrm{n}(\%)\end{array}$ & & \\
\hline Usia (tahun) & $1-7$ & $77(64,7)$ & $42(35,3)$ & $1,8(1,0-3,1)$ & 0,037 \\
Lama hari rawat (hari) & $\geq 8$ & $48(50,5)$ & $47(49,5)$ & & \\
& $1-7$ & $94(76,4)$ & $29(23,6)$ & $6,3(3,4-11,4)$ & 0,000 \\
Komorbiditas & $\geq 8$ & $31(34,1)$ & $60(65,9)$ & & \\
& Tidak ada & $74(63,8)$ & $42(36,2)$ & $1,6(0,9-2,8)$ & 0,082 \\
Rerata Jumlah Obat yang & Ada & $51(52,0)$ & $47(48,0)$ & & \\
Diberikan & $1-4$ & $87(76,3)$ & $27(23,7)$ & $5,3(2,9-9,5)$ & 0,000 \\
\hline
\end{tabular}

$\mathrm{p}<0,05$ pada IK95\%. Adapun hasil analisis bivariat tertera pada Tabel 4.

\section{Pembahasan}

Berdasarkan hasil penelitian diketahui bahwa 89 kunjungan rawat inap $(41,6 \%)$ berpotensi mengalami minimal satu kejadian PIOO dengan tingkat keparahan kontraindikasi, berat, atau sedang. Persentase ini tidak jauh berbeda apabila dibandingkan dengan hasil penelitian lain yang juga dilakukan pada pasien anak. Feinstein $\mathrm{dkk}^{15}$ melaporkan bahwa sedikitnya terdapat satu pasang kombinasi obat yang berpotensi menyebabkan interaksi pada 498.956 (49\%) kasus rawat inap pasien anak di rumah sakit yang tergabung dalam Children's Hospital of Philadelphia. Selain itu, penelitian terkait PIOO yang dilakukan terhadap pasien dewasa di Brazil juga memberikan gambaran yang serupa. Disebutkan bahwa terdapat minimal satu pasang kombinasi obat yang berpotensi menyebabkan interaksi pada 887 resep (49,7\%) menggunakan perangkat lunak pemindai interaksi obat Micromedex Drug Reax ${ }^{\oplus}{ }^{16}$

Berdasarkan data 214 kunjungan rawat inap pada periode Januari - Desember 2014, diperoleh 107 pasang jenis obat yang dapat menyebabkan PIOO dengan total frekuensi kejadian sebanyak 1000 kasus. Angka kejadian PIOO yang tinggi dikhawatirkan dapat berakibat buruk terhadap pasien. Sedikitnya, interaksi obat bertanggung jawab terhadap 20\%-30\% timbulnya efek samping obat yang memerlukan perhatian klinis. ${ }^{8}$ Hal tersebut diketahui dapat memperpanjang lama hari rawat, menambah biaya perawatan, bahkan menyebabkan kematian. ${ }^{6,10,11}$
Namun, apabila dibandingkan dengan hasil penelitian PIOO lain yang dilakukan pada pasien kanker, kejadian PIOO pasien leukemia akut pada anak yang menjalani rawat inap di RSCM memiliki persentase lebih kecil. Berdasarkan studi Van Leeuwen $\mathrm{dkk}^{17}$ diidentifikasi 348 pasang kombinasi obat yang berpotensi menyebabkan interaksi pada 161 pasien kanker dewasa dengan persentase kejadian 58\%. Diskrepansi ini mungkin terjadi karena perbedaan desain penelitian, waktu penelitian, karakteristik sampel, dan perbedaan metode dalam melakukan identifikasi PIOO. ${ }^{6}$

Berdasarkan hasil penelitian diketahui bahwa sebagian besar PIOO pasien leukemia akut pada anak yang menjalani rawat inap di RSCM selama tahun 2014 bersifat berat. Diperoleh 65 (60,70\%) dari 107 pasang kombinasi PIOO yang teridentifikasi berisiko menyebabkan gangguan menetap atau kematian sehingga dibutuhkan intervensi medis untuk meminimalisasi dampak klinis yang mungkin terjadi. ${ }^{15}$

Persentase tersebut tidak jauh berbeda dengan hasil penelitian PIOO pada pasien anak yang menjalani rawat inap di Philadelphia. Sebagian besar PIOO bersifat berat dengan persentase $41 \%$, diikuti sedang $(28 \%)$, ringan $(11 \%)$, dan kontraindikasi $(5 \%) .{ }^{15}$ Namun, apabila dibandingkan dengan hasil penelitian yang dilakukan pada pasien anak di University Hospital Olomouc, Ceko, hasil penelitian ini jauh lebih besar. Langerova melaporkan bahwa angka kejadian PIOO pada pasien anak diketahui sebesar 3,83\% dengan tingkat keparahan sedang hingga berat sebesar $0,47 \%{ }^{6}$

Diskrepansi ini mungkin terjadi karena perbedaan klasifikasi tingkat keparahan PIOO pada perangkat lunak pemindai interaksi obat yang digunakan. ${ }^{16}$ Seba 
Sri Wulandah Fitriani dkk: Angka kejadian dan faktor yang memengaruhi potensi interaksi obat dengan obat pasien leukemia akut

gai contoh, kombinasi fenitoin dengan kortikosteroid diklasifikasikan sebagai interaksi obat dengan tingkat keparahan berat menggunakan perangkat lunak LexiInteract. Namun, menurut Micromedex Drug-Reax dan Drug Interaction Fact, kombinasi keduanya dinilai memiliki tingkat keparahan sedang. ${ }^{8}$

Untuk membatasi sensitivitas perangkat lunak dalam melakukan identifikasi PIOO, hanya kombinasi PIOO yang bersifat kontraindikasi, berat, atau sedang yang diikutsertakan dalam perhitungan prevalensi dan analisis faktor risiko. Berdasarkan hasil penelitian, diperoleh 24 pasang kombinasi obat yang dapat menyebabkan PIOO dengan tingkat keparahan ringan dengan total frekuensi kejadian sebanyak 56 kasus. Kombinasi PIOO yang bersifat ringan tidak diikutsertakan karena hanya memberikan sedikit pengaruh terhadap respon terapeutik obat, dampak klinis kurang signifikan, dan tidak dibutuhkan perubahan regimen terapi. ${ }^{8}$ Salah satu contoh kombinasi PIOO ringan yang banyak terjadi pada penelitian ini adalah kombinasi alopurinol dengan amoksisilin. Meski pernah dilaporkan adanya peningkatan insidensi ruam kulit, namun belum diperoleh angka kejadian yang cukup signifikan sehingga tidak dibutuhkan perubahan regimen terapi. ${ }^{18,19}$

Menurut Micromedex ${ }^{\oplus}$ Drug Reax, tingkat keparahan kontraindikasi didefinisikan sebagai tingkat keparahan interaksi obat tertinggi yang membutuhkan pengawasan secara ketat terhadap dampak klinis yang tidak dikehendaki apabila kedua obat diberikan secara bersamaan..$^{20}$ Berbeda dengan kompendium Vidal, Micromedex ${ }^{\oplus}$ Drug Reax tidak membedakan kelompok kontraindikasi menjadi kontraindikasi absolut dan relatif. ${ }^{21}$ Berdasarkan hasil analisis Micromedex ${ }^{\bullet}$ Drug Reax pada sampel diketahui bahwa kombinasi PIOO yang memiliki tingkat keparahan kontraindikasi dengan frekuensi paling sering adalah flukonazol dan ondansetron.

Kejadian mual dan muntah akibat induksi kemoterapi (chemotherapy induced nausea and vomiting/CINV) dialami oleh $70 \%-80 \%$ pasien yang memperoleh obat kemoterapi. Hal tersebut disebabkan aktivasi reseptor neurotransmitter yang berlokasi di chemoreceptor trigger zone (CTZ), pusat muntah, dan saluran cerna. Sekitar 10\%-30\% pasien menolak melakukan kemoterapi karena pernah merasakan efek samping tersebut. Ketidakpatuhan pasien terhadap regimen kemoterapi dapat berdampak pada peningkatan angka morbiditas yang signifikan. Oleh karena itu, perlu dilakukan pemberian antiemetik sebagai langkah pencegahan terjadinya CINV. ${ }^{22}$ Ondansetron sebagai anti-serotonergik merupakan agen profilaksis utama terhadap CINV yang bekerja dengan mengantagonisasi reseptor antagonis 5-HT3 yang terdapat pada CTZ di area postrema otak dan juga aferen vagal saluran cerna. ${ }^{23}$

Pasien leukemia sering mengalami penurunan daya tahan tubuh, baik akibat perburukan gejala klinis maupun sebagai respon kemoterapi sehingga pasien rentan terinfeksi virus, jamur, dan bakteri. ${ }^{12}$ Flukonazol sebagai obat pilihan untuk profilaksis infeksi jamur Candida sp. pada pasien febril neutropenia merupakan inhibitor sitokrom P450, terutama CYP2C9, CYP2C19, dan CYP3A4 yang dapat menghambat metabolisme obat yang bekerja pada jenis sitokrom tersebut, termasuk ondansetron.

Pemberian ondansetron dan flukonazol secara bersamaan diketahui telah menunjukkan perpanjangan interval QT. Flukonazol berpotensi menyebabkan interaksi farmakodinamik melalui penghambatan metabolisme ondansetron sehingga kemudian terjadi peningkatan konsentrasi ondansetron dalam darah dan meningkatkan risiko efek samping perpanjangan interval QT. ${ }^{24}$

Berdasarkan data terbaru FDA, diketahui bahwa efek samping tersebut terjadi pada pemberian ondansetron iv dalam dosis tunggal $32 \mathrm{mg}$. Ondansetron tetap dapat diberikan sebagai profilaksis CINV dalam dosis rendah, yaitu $0,15 \mathrm{mg} / \mathrm{kg}$ dalam 3 kali pemberian dengan dosis maksimal $16 \mathrm{mg}$ pada setiap pemberiannya. Dengan demikian, apabila diperlukan pemberian flukonazol dan ondansetron secara bersamaan perlu dipastikan bahwa dosis ondansetron tidak melebihi dosis yang diizinkan dan diperlukan pemeriksaan EKG secara rutin. ${ }^{25}$

Kejadian PIOO dari regimen pengobatan pasien kanker secara teori dipengaruhi oleh faktor polifarmasi, keadaan imunokompromais pasien, komorbiditas, dan lama hari rawat. ${ }^{9}$ Berdasarkan hasil analisis bivariat diperoleh perbedaan signifikan secara statistik $(\mathrm{p}<0,05)$ pada faktor usia, lama hari rawat, dan rerata jumlah obat yang diberikan. Faktor usia, lama hari rawat, dan rerata jumlah obat yang diberikan berpengaruh signifikan terhadap kejadian PIOO dengan nilai OR 1,8 terhadap pasien berusia $>7$ tahun, 6,3 terhadap pasien dengan lama hari rawat $>7$ hari, dan 5,3 terhadap pasien dengan rerata pemberian $>4$ obat per hari. 
Sri Wulandah Fitriani dkk: Angka kejadian dan faktor yang memengaruhi potensi interaksi obat dengan obat pasien leukemia akut

Tidak terdapat perbedaan bermakna kejadian PIOO pada kelompok pasien leukemia yang dibedakan berdasarkan komorbiditas. Dengan demikian, dapat disimpulkan bahwa komorbiditas tidak memberikan kontribusi sebagai faktor risiko terjadinya PIOO pada pasien leukemia yang menjalani rawat inap di RSCM periode Januari - Desember 2014. Komorbiditas yang diperoleh, antara lain, febril neutropenia, hiperleukositosis, pneumonia komunitas, sepsis, gagal jantung, herpes, diare, dan gizi buruk marasmik.

Identifikasi dan strategi penanganan PIOO pada pasien kanker memiliki tantangan tersendiri, di antaranya, ${ }^{9}$

- Komunikasi yang kurang antara dokter spesialis onkologi dengan tenaga kesehatan lain dan/atau keluarga pasien.

- Pasien memiliki kecenderungan untuk mengkonsumsi obat lain, termasuk sediaan herbal yang tidak disadari dapat mengganggu respon protokol terapi pasien.

- Efek klinis yang merugikan akibat PIOO dapat disalahartikan dengan efek samping. akibat kemoterapi sehingga seringkali diabaikan.

- Hampir seluruh agen kemoterapi memiliki indeks terapi yang sempit sehingga sulit untuk memodifikasi dosis obat tanpa mempengaruhi khasiat atau efek samping obat tersebut.

Sampai saat ini, belum diketahui cara terbaik untuk mencegah terjadinya interaksi obat. Penggunaan program elektronik pemindai interaksi obat menjadi salah satu cara yang efektif dalam meningkatkan kewaspadaan tenaga kesehatan terhadap kejadian tersebut. ${ }^{14}$ Namun, program elektronik pemindai interaksi obat memiliki kelemahan berupa sensitivitas yang rendah sehingga memungkinkan adanya identifikasi PIOO positif palsu. Oleh karena itu tetap diperlukan adanya peran farmasi klinis dalam mengidentifikasi, memprediksi, dan mengevaluasi dampak klinis akibat PIOO tersebut. ${ }^{26}$

\section{Daftar pustaka}

1. American Cancer Society. Leukemia childhood overview. Atlanta: American Cancer Society; 2013.

2. Meidiana B. Analisis faktor kejadian relapse pada anak dengan leukemia di RSCM [tesis]. Depok: Fakultas Ilmu Keperawatan Universitas Indonesia, 2012.
3. American Cancer Society. Survival rates for childhood leukemias. American Cancer Soc [serial online] Feb 2016 [disitasi 9 Jul 2016]; 2016. Didapat dari: URL: http:// www.cancer.org/cancer/leukemiainchildren/detailedguidel childhood-leukemia-survival-rates.

4. Permatasari E, Windiastuti E, Satari HI. Survival and prognostics factors of childhood acute lymphoblastic leukemia. Paediatrica Indonesiana 2009;49: 365-71.

5. Cremades J, Gonzalo M, Arrebola I. Relationship between drug interactions and drug-related negative clinical outcomes. Pharmacy Practice 2009;7:34-9.

6. Langerova P, Prokes M, Konvalinka M, Furstova J, Urbanek K. Incidence of potential drug interactions in medication prescriptions for children and adolescents in the University Hospital Olomouc, Czech Republic. Europe J Pediatric 2013;172:631-8.

7. Bhagavathula AS, Berhanie A, Tigitsu H, Abraham Y, Getachew Y, Khan TM, Unakal C. Prevalence of potential drug-drug interactions among internal medicine ward in University of Gondar Teaching Hospital, Ethiopia. Asian Pacific J Tropical Biomedicine 2014;4:S204-8.

8. Hadjibabaie M, Badri S, Ataei S, Moslehi AH, Karimzadeh I, Ghavamzadeh A. Potential drug-drug interactions at a referral hematology-oncology ward in

9. Iran: a cross-sectional study. Cancer Chemotheraphy Pharmacology 2013;71:1619-27.

10. Ussai S, Petelin R, Giordano A, Malinconico M, Cirillo D, Pentimalli F. A pilot study on the impact of known drug-drug interactions in cancer patients. J Experimental \& Clinical Cancer Research 2015;34:1-6.

11. Becker M, Kallewaard M, Caspers PWJ, Visser LE, Hubert GML, Stricker B. Hospitalisations and emergency department visits due to drug-drug interactions: a literature review. Pharmacoepidemiology and Drug Safety 2007;16:641-51.

12. Skvrce NM, Sarinic VM, Mucalo I, Krnic D, Bozina $\mathrm{N}$, Tomic S. Adverse drug reactions caused by drugdrug interactions reported to Croatian Agency for medicinal products and medical devices: a retrospective observational study. Croatian Medical J 2011;52:604-14.

13. Haidar C, Jeha S. Review: drug interactions in childhood cancer. Lancet Oncology 2010;12:92-9.

14. Buajordet I, Ebbesen J, Erikssen J, Brors O, Hilberg T. Fatal adverse drug events: the paradox of drug treatment. J Internal Medicine 2001;250:327-41.

15. Riechelmann RP, Tannock IF, Wang L, Saad ED, Taback NA, Krzyzanowska MK. Potential drug interactions and duplicate prescriptions among cancer patients. J National Cancer Institute 2007;99:592-600. 
Sri Wulandah Fitriani dkk: Angka kejadian dan faktor yang memengaruhi potensi interaksi obat dengan obat pasien leukemia akut

16. Feinstein J, Dai D, Zhong W, Freedman J, Feudtner C. Potential drug-drug interactions in infant, child, and adolescent patients in children's hospitals. Pediatrics 2015;135:e99-e108.

17. Cruciol-Souza JM, Thomson JC. A pharmacoepidemiologic study of drug interactions in a brazilian teaching hospital. Clinics 2006;61:515-20.

18. Van Leeuwen, Swart, Boven, Boom, Schuitenmaker, Hugtenburg. Potential drug interactions in cancer theraphy: a prevalence study using an advanced screening method. Annals of Oncology 2011;22:2334-41.

19. Kaur SP, Rao R, Nanda S. Amoxicillin: A broad spectrum antibiotic. International J Pharmacy and Pharmaceutical Sciences 2011;3:30-7.

20. Fredj NB, Aouam K, Chaabane A, Toumi A, Rhomdhane FB, Bhoughattas N, Chakroun M. Hypersensitivity to amoxicillin after drug rash with eosinophilia and systemic symptoms (DRESS) to carbamazepine and allopurinol: a possible co-sensitization. British J Clinical Pharmacology 2010;70: 273-76.

21. Smithburger PL, Kane-Gill SL, Seybert AL. Drug-drug interactions in cardiac and cardiothoracic intensive care units. Drug Safety 2010;33:879-88.

22. Vitry AI. Comparative assessment of four drug interaction compendia. British J Clinical Pharmacology
2006;63:709-14.

23. Schnell FM. Chemotherapy induced nausea and vomiting: the importance of acute antiemetic control. The Oncologist 2003;8:187-98.

24. Dewoto HR, Louisa M. Serotonin, obat serotonergik, dan obat antiserotonergik. Dalam: Gunawan SG, Setiabudy R, Nafrialdi, Elysabeth, penyunting. Farmakologi dan terapi. Edisi kelima. Jakarta: Departemen Farmakologi dan Terapeutik Fakultas Kedokteran Universitas Indonesia;2007:h.268-97.

25. Espinosa FP, Carrasco D, Soler F, Merino R, Nieto DR, Miro E. Pharmacoepidemiological study of drug-drug interactions in oncohematological pediatric patients. International J Clinical Pharmacy 2014;36:1160-9.

26. Hafermann MJ, Namdar R, Seibold GE, Lee R. Effect of intravenous ondansetron on QT interval prolongation in patients with cardiovascular disease and additional risk factors for torsades: a prospective, observational study. Drug Healthcare and Patient Safety 2011;3:53-8.

27. Chan A, Yap KY, Koh D, Low XH, Cheung YT, Oncoinformatics group. Electronic database to detect drugdrug interactions between antidepressants and oral anticancer drugs from a cancer center in Singapore: implications to clinicians. Pharmacoepidemiology and Drug Safety 2011;20:939-47. 